\title{
Sustainable Governance and Knowledge-based Economy - Prerequisites for Sustainable Development of the Developing and Transitional Economies
}

\begin{abstract}
By Kristina Jovanova*
Economic globalization results in unbalanced development and growing inequality between the centre and the periphery of the global economic map. This process is driven by the expansionist policies of the corporations and the financial capital, being in collision with the social protection system. Markets are good for wealth creation, but they fail to take care of the citizens' social needs. Social justice is a public good that can be provided for only by means of the political process. Globalization fails to meet the needs of the ultimate beneficiary of the development processes - the citizen. The modality in which economic localization foundations were set in the development and transitional economies, did not exhibit clear development capacities in order to improve the global position of these countries. Alternative development strategies are required in order to keep the territorial integrity of the nation-state and radical reforming of the central government role in the process is a prerequisite. The main driving force of the sustainable governance concept refers to the participation, knowledge and information distribution and cooperation among stakeholders. Economic prosperity is dependent on the effectiveness in production, collection and use of knowledge in the economic processes. Economy converts into a hierarchy of networks and what comes out as a result is a network society in which individual or corporative capacity for participation and networking determines the socio-economic position. Knowledge - Based Economy (KBE) refers to an economy that applies information resources, technology and knowledge into the economic development processes. Innovations entail increased communication intensity and feedback among companies, academic institutions, laboratories, consumers. They are a result of a number of interactions and synergies of specific innovative systems that tend to expand outside national borders, ideally becoming global, incorporating numerous global-local connections.
\end{abstract}

JEL Codes: Q01, F60, F00

Keywords: globalization, localization, sustainable development, knowledgebased economy, governance

\section{The Root of the Problem}

The paper is exploring the modalities of sustainable governance and economic activities that would counterbalance the demonstrated deficiencies of the global economic order dominated by mega - capitalism and would improve the position

*National Programme Officer, Organization for Security and Co-operation in Europe (OSCE) Mission to Skopje, North Macedonia. 
of the developing and transitional economies on the global economic map (Dicken 2007).

The first introductory section penetrates into the root of the problem, casting light on two major segments: 1) the combination of unbalanced distribution of production factors, knowledge and technology and 2) the presence of corruption, captured state by corporative capital and lack of sustainable governance instruments.

The research develops into a presentation of literature reviewed in order to develop the thesis and elaborate the main starting points, followed by a methodological approach for proving the existent discrepancies on the global economic map, projected in the centre-periphery theory.

Discussions, findings and conclusions follow as a result of the elaborated thesis and starting premises.

\section{Marginal Productivity Factor}

The capitalism driving force is profit maximization that is realized by means of accumulating extra value incorporated into the goods and services traded and the underpaid labour force. This system functions either by intensification of labour exploitation or by expanding production and introduction of more efficient and technologically innovative methods that are increasing the trade value for greater profit. The contradiction inherent to the process is the following - the more reduced labour time, the less labour value traded goods incorporate.

According to the theory of marginal productivity, in a modern high tech economy not all labour market participants are able to valorise their labour. Labour market puts on the surface only those who possess specific skills and knowledge. The rest are out on the margins of the system. Moreover, digitalization and robotics enable for production without human input. Unprecedented in the history of mankind, production without human labour input is possible. Hence, technological development appears to be the main factor for the rising inequality, while labour supply needs to correspond to the labour demand in order to avoid it.

If goods and services cannot result in profit without their realization on the market and unpaid labour force excluded from the production system cannot consume the rising supply in goods and services, does this mean the end of mass production is announced? Definitely not, as the financial sector takes over by opening credit lines and upbringing the capital on the throne of the mega capitalist order (Stiglitz 2015). In the long run, labour factor position additionally worsens by falling down into the spiral of indebtedness under the mercy of the financial institutions lead by the individual need for profit. The pattern reflects from individual to national level in most of the transitional and developing countries (Bartlett and Uvalić 2013). 


\section{Asymmetry of Information, Non-Transparency, Corruption and Speculative Capital}

The imperfections of the market mechanisms are not properly treated by national policies. A major percentage of the inequality also results from inactivity and lack of adequate government policies, selective and not transparent decisionmaking, corruption and breaking the rules of the system, even more, producing rules as per the preferences of the ruling political and financial elites (Ceriani and Dávalos 2014). The situation worsens when governments are controlled by financial oligarchs interested in the less transparent market. The practice is not exclusively applicable to developing and transitional countries, but also takes place globally and in rather developed economies. Yet, the instruments and tools are different and extend from non-objective and hidden information to using financial market derivatives that create fabricated reality on the real values of assets. The last was one of the main reasons for the 2008 financial crisis. Stiglitz rightfully calls them "financial weapons for mass distraction" in his 2008 book "The Price of Inequality". When these financial derivatives that denominate virtual and speculative capital are subject to trade, asymmetry of information between buyer and a seller allows seller (financial institution) to extract extra profit. This is a pure speculative transaction.

Capital, in its nature, needs to circulate. Yet, not all capital transactions lead towards creating added values. When capital rather accumulates due to the payment of credit interest, it is called speculative capital. The mass expansion of speculative capital in a form of financial derivatives and their subsequent trade on the financial market overpassed the amount of trade transactions in goods and services. Even though of suspicious nature, financial derivatives normally tend to be backed up by real assets and value by borrowers on the market, shifting the risk of failure on the account of citizens' budgets, thus paving the road to a long-term economic instability. Moreover, government policies are inclined towards bailing out corporative failures on the financial market (for example, financial crisis 2008).

The inherent tendency of the speculative capital to move from highly developed towards underdeveloped countries, that is, from countries with low towards ones with high interest rates, constitutes a potential threat for developing and transitional economies of irreversibly falling into the spiral of indebtedness. Financial industry exercises high pressure on these countries by using speculative capital for financing trade balances with one final goal - realization of goods and services on the market and creating profit. 


\section{Economic Globalization - Irreversible Trend that Fails to Meet Global Social Needs: A Review}

The evident exponential rise of the financial derivatives in the past decades ${ }^{1}$ in combination with the politico-economic approach in defining the process, leads to the conclusion that economic globalization is a process of privatization of the world economic resources by the owners of capital, very often virtual and hybrid capital. Under the same logic, it represents a process of transformation of the territorial (national) state into a market-corporate state, a new stage in the development of capitalism called mega - capitalism, which (dialectically) equals to the stage of capitalist development that precedes post - capitalism and post market society, as seen by Marx (Shachtman 1962), Keynes in his book "Economic Possibilities for our Grandchildren", Hilferding in "Finance Capital", or from the latest history, by Peter Drucker in "Post-Capitalist Society" and Robin Hahnel in "Of the People, By the People: The Case for a Participatory Economy", from 2012. The free capital movement is the basic characteristic of the economic globalization. Countries compete to attract capital, a fact that limits their own sovereignty and power to tax it. In the meantime, the movement of the labour force is strictly regulated. Hence, globalization radically modifies economic and societal arrangements in a direction of decreasing the state control over the economy. The effect is accelerated by the activities of neoliberal politicians and economists that act as corporative capital agents with a final goal of decreasing the power of the state over its national economy and opening the road to an expansion of capital and profit accumulation.

There is an evident political trend that creates extra profit for elite structures not due to their objective productivity and contribution towards social welfare, but due to corruptive connections with the ruling power, called "rent seeking" (Stiglitz 2012). This phenomenon is a very common practice in the transitional and developing economies and is very far away from a state of optimal and equitable distribution of the social wealth where the personal reward should correspond to the benefit delivered to the society. Literature offering solutions for the distribution of resources is immense. Market fundamentalists (Adam Smith, Milton Friedman) suggest that distribution of resources is most effectively and efficiently achieved within the market mechanisms system and that each intervention into the system would decrease the overall efficiency of the economy. From that perspective only, economic globalization is ultimately a successful project - free competition on a global level incites inventive and entrepreneurial talents and fosters technological development processes. But, the economic globalization is in a collision with the social protection system. As John Maynard Keynes, Joseph Stiglitz and Paul Krugman imply, markets are good for wealth creation but fail to serve the social needs of citizens. While market functions blindly in accordance with individual interests not giving moral judgement of correctness, society cannot function

\footnotetext{
${ }^{1}$ The activity of global financial derivatives reached 457 trillion euros in 2007 and 553 trillion in 2015, according to the Statistical Release, OTC Derivate Statistics at End-June 2015, Monetary and Economic Department, Bank for International Settlements, November 2015. Retrieved from: https:// www.bis.org/publ/otc_hy1511.pdf.
} 
without differentiating between right and wrong. The collective distinction between right and wrong is up to politics that fails to bring societally acceptable decisions in a world that lacks strong moral platform (Soros 2011). Political action is necessary even for creation and maintaining the market per se. The global crisis in 2008 demonstrated that markets are truly volatile; they possess internal power but lack inherent system moral (Down 2008).

Profit dominates moral values. Underdeveloped and transitional countries remain affected by the unbalanced distribution between private and public goods with the mega - capitalist trends working in favour of accumulating private goods in the hands of few political elites (Mason 2015). As financial markets are subject to crises, they do not strive towards equilibrium, but facilitate the free trade of goods and services between voluntary participants in favour of their individual needs, rather neglecting the collective needs of people, such as order, law enforcement and social justice. These "public goods" can be provided for with political process only. If the main advantage of the markets is considered the efficiency (situation when supply equals demand in quality and quantity) and their inefficiency is obvious (inability to absorb the available human resources and labour potential) than logical conclusion prevails that globalization without adequate coordination and strengthening of the international political and societal arrangements, leads to inequality. If citizens' welfare is the imperative of the democratic systems, we cannot afford to maintain a kind of globalization system that appears to be the main reason for the ever-growing inequality due to unfair rules of the game or even the absence of them.

The positive sides of the economic globalization per se are not contested, but the manner in which globalization is managed. Globalization trend cannot and should not be stopped. Yet, the main challenge remains: how can we direct the process towards achieving win-win outcome for all involved stakeholders. Nobel Prize winner Amartya Sen (Sen 1999) claims that GDP quantitative indicator is not an appropriate measure of human welfare and that globalization 'winners' might compensate the "losers" and yet gain. The problem is the absence of legitimate international equivalent of the political processes conducted at the national level. Market challenges became global and politics remains deeply rooted in the sovereignty of the national states. This contributes to increasing the gap between rich and poor countries.

According to the latest World Bank indicators (World Bank Group 2014, 2015, 2019), the wealthiest 1 per cent of the citizens on Earth earns as much as the poorest 57 per cent together and 10 percent of the world's population lived in 2015 on less than US $\$ 1.90$ per day. This type of system functions in favour of the top level and is so inefficient that the profit of the top is smaller than the loss of the bottom in the societal pyramid. The biggest loss appears to be the trust - lost trust in the democracy and justice.

Technological development is advancing at a very high speed the humankind has never seen before the twenty-first century and it is very hard to predict the future. Same technology can create very different kinds of societies. For example, South and North Korea have had access to exactly the same technology but have chosen to employ it in very different ways (Harari 2017). Yet, the latest 
technology development trends leave open space for one very obvious move eliminating the role of the central governments (nation-states) as a direct economic development factor and opening space for networking on a global-local level, creation of knowledge clusters and developing of Knowledge-Based Economy.

\section{Knowledge-Based Economy: A Counterbalance to the Mega Capitalism}

Knowledge, as an integral part of the so-called 'human capital' and technology, has always been the driving force of the economic development, but only as far as in the last couple of decades its importance has been recognized as a growing crucial development factor. Knowledge-Based Economy (KBE) refers to an economy that applies information resources, technology, specific skills and knowledge for achieving economic development. The idea of knowledge playing a key economic role is not new. Adam Smith referred to "new type of specialists that brings an important contribution in creating economically useful knowledge" (Mueller 2015). Friedrich List (List 1841) acknowledged "institutions that contribute to the development of productive forces by means of creation and distribution of knowledge". The idea of Schumpeter (McCraw 2007) on innovations as important economic dynamics factor was followed by students such as Galbraith, Goodwin and Hirschman.

The notion of KBE is closely linked to the work of the management theorist Peter Drucker and the sociologist Daniel Bell, (Drucker 1959, Bell 1973). Yet, the term "Knowledge Economy" and its synonym "Knowledge-Based Economy" were not widely spread up to the early 90 -ties of the last century. Since then, the development of KBE turned into the leading principle of the economic development policies in the developed countries, despite its incomplete definition and attempt to be contested as a development concept. The term "KnowledgeBased Economy" resulted in total recognition of the role of knowledge and technology in economic growth and development. For example, OECD countries from the beginning of this millennium are increasingly dependent on production, distribution and use of knowledge in the context of economic processes. Economic output and employment in the technological intensive sectors have increased in the countries from the global centre with the fastest rate ever noted. In the last decade, the proportion of high technology in the industrial production of OECD has doubled and is estimated that in the biggest number of developed countries, more than 50 per cent of GDP is knowledge-based.

The definition of KBE combines the approach of the World Bank and OECD: "Knowledge-Based Economy is the type of economy based on economic incentives and institutional regime which stimulates acquiring, creation, dissemination and use of knowledge and flow of information for increasing the growth and welfare, as well as effective educational systems for development of skills, ICT, research, development and innovation". According to Ian Brinkley, former director of Knowledge Economy Programme of Work Foundation, the KBE idea may be operationalized by 1) defining the knowledge industries (for example, knowledge based services); 2) knowledge intensive labour force (example, holders of certificates in most contemporary professional codes); 3) 
knowledge sources and assets (research and development) and 4) knowledge based services (volume of trade in knowledge - based industries).

These are narrow approaches in defining KBE. Alternatively, KBE can be defined as a concept that incorporates complex processes of socio-economic restructuring, followed by growing importance of information flow and processing and creation of knowledge though the entire economic activities' process. This concept involves investment in science, technology, engineering and maths (Science, Technology, Engineering and Mathematics - STEM), increased number of educated workers and consumers and the development of new industry sectors.

The Knowledge-Based Clusters and similar instruments that constitute an integral part of the KBE concept are presented in Table 1.

Table 1. Knowledge Clusters and Similar Instruments

\begin{tabular}{|l|c|c|}
\hline Concept & Short definition & Quantification (example) \\
\hline $\begin{array}{l}\text { K-cluster } \\
\text { (knowledge cluster) }\end{array}$ & $\begin{array}{c}\text { Agglomeration of } \\
\text { institutions where } \\
\text { knowledge is input and/or } \\
\text { output }\end{array}$ & $\begin{array}{c}\text { Number of organizations per } \\
\text { location }\end{array}$ \\
\hline $\begin{array}{l}\text { K-hub } \\
\text { knowledge hub) }\end{array}$ & $\begin{array}{c}\text { Local innovation system, } \\
\text { centre of network } \\
\text { production and distribution } \\
\text { of knowledge }\end{array}$ & $\begin{array}{c}\text { Number of human resources } \\
\text { and labour force focused on } \\
\text { knowledge and their output } \\
\text { patents, software, documents } \\
\text { produced) }\end{array}$ \\
\hline K-architecture & $\begin{array}{c}\text { Structures and institutions } \\
\text { for communication and } \\
\text { knowledge flow }\end{array}$ & $\begin{array}{c}\text { ICT management, regular } \\
\text { meetings and knowledge } \\
\text { exchange initiatives }\end{array}$ \\
\hline Epistemological relief & $\begin{array}{c}\text { Locations with high or low } \\
\text { knowledge intensity }\end{array}$ & $\begin{array}{c}\text { Regional R\&D, costs, location } \\
\text { of K clusters and knowledge } \\
\text { centres }\end{array}$ \\
\hline
\end{tabular}

Source: Dev Singla 2008.

These trends necessarily lead to the revision of the existing theories and models. Traditional production factors based on labour, capital, material and energy where knowledge and technology are external factors are replaced with a new concept where knowledge represents direct productivity factor.

For the purpose of measuring and monitoring the KBE development, World Bank developed Knowledge Economy Index (KEI), using a four pillars framework: 1) economic initiative, incentive and an institutional regime in support of KBE; 2) educated population ready to create, disseminate and use knowledge; 3) efficient system of companies ready to absorb innovation and technology created, research centres, universities, consultancies ready to contribute to the global knowledge aggregate development and 4) information and communication infrastructure for facilitation of effective creation and processing of knowledge and information. According to the World Bank data for 2012, the highest KEI has been calculated for Sweden and Scandinavian countries, EU, USA, Switzerland, Australia and New Zeeland.

Developing and transitional economies lack the majority of all the KEI indicators. 


\section{Methodology: Center vs. Periphery on the Global Economic Map - The} Unsustainable Reality and the Need for Localization

For the purpose of achieving the defined goals, the paper uses classical research methods, such as analysis, synthesis, induction, deduction, description, comparing, abstraction, historical method and similar. The theoretical component includes contemporary literature in the field of global and local economy, quotations from renowned authors from journals, statistical data from reports published by international governmental and nongovernmental organizations and internet pages. However, the main methodological platform for analysing the problem of the developing and transitional economies is the centre-periphery theory.

According to the centre-periphery theory, global capitalism has contradictory structure. It is developing into dominating socio-economic system based on the appropriation of the extra value by means of monopolistic instruments. The monopolistic position of the centre (countries that enjoy control over information, technology and knowledge) enables accumulation of the added extra value from the countries satellites in the periphery of the global economic map, later on, used for augmentation and centralization of the capital. Instruments of this process are the prices of products and services on the market in the economic branches with a greater organic composition of the production factors (greater technology versus labour). Respectively, the unbalanced territorial distribution of such economic branches creates unbalanced development and inequality among territories on the global economic map. This is the inherent discriminatory practice of mega capitalism, based on the exclusive right over contemporary technology, the latter being a factor of above average productivity of the centre. Contrary to the interests of the periphery, globally speaking, the technological advantage of the centre has been internalized as a cost on the global level directed towards the disadvantaged on the periphery. Moreover, the periphery is unable to compete structurally with the centre, as in the era of financial capital domination, the contemporary economic reforms offered by the global financial institutions are of a rather monetary character causing damage to the production infrastructure of the periphery and opening financial channels for crediting the mass consumption of products created in the centre. The interventionist instruments used thereby are so untypical for the neoliberal economic provenience, as great paradox has been created: by state interventions from the centre promoted is a capital-labour model in which periphery countries would ultimately lose their power over labour in favour of the Transnational Corporations (TNC) and ultimately eliminating the nation - state and converting it into corporate state with an eliminated social component.

These policies enjoy strong support from the global centre, USA, the only country with a veto right in the IMF and lead to a rise of speculative financial assets detrimental to the development of entrepreneurship and structural reforms in the periphery countries (developing and transitional). This results in unproductive spending, unemployment and inefficiency. By owing monopolistic position over highly technology intensive production and offering it to the periphery, the centre pumps out the accumulation of capital from the periphery deepening the 
development gap. Explained in this manner, the centre-periphery theory refutes western theories according to which centres are sources of development trends for the developing and transitional economies (the periphery). To the contrary, periphery corporate state capitulated before capital itself, eliminating the need for its taxation just to be able to attract it.

This type of capitalist order that takes its major driving force from the technological supremacy of one global centre (the Silicon Valley) backed by the voluntarism of the speculative capital and cultural individualism is politically, societally and first of all, economically unsustainable. When speculative financial capital is the only binding mechanism between centre and periphery, there is an open space for expansion of corruptive, corrosive and criminal structures, distorting the system of universal human values.

The postulates of a contemporary understanding of a democratic society are in collision with the practical tendencies of the global economy functioning. If we assert that democratic government belongs to citizens and exists for citizens then it would be very hard to assert that the current political system trends in developing and transitional economies are democratic. The power remains with the rich financial elites that have captured the corporate state and spread towards the lowest society cell in the local communities, using mass and sophisticated public political campaigns. If the government is, in fact, functioning for improving the welfare of citizens, they must be allowed to smoothly participate in the decision making on issues of their direct interest. Citizens' participation in decision making processes can only be done efficiently at the local level of government, at the level of their communities, exactly where resources come from, where challenges are felt and where common goals and interests are shared among community members.

In the rapidly changing global economic environment, the shift in perceptions and understanding of the economic processes leads to a transition from economic globalization to economic localization and ultimately, glocalization. This process needs to be followed by a subsequent shift in policies and politics at the national and international level. The political focus needs a shift from protecting to limiting the power of TNC (Transnational Corporations).

The new technological era of the K5 wave (Quigley 2012) has the potential to end the destructive trend. Yet, this requires strong political will for decentralization of the global economy into polycentric local structures with fair game rules and economic inclusion of the periphery countries. There is no need for choosing between unlimited mega - capitalism and the opposite - back to communism, as both are unsustainable. Fruitful interaction between the power of knowledge and social welfare is imperative.

Local initiative need to be given a space for action and realization, currently being suffocated by the immense state subsidies the corporate state offers to the powerful business elites. Global economic entities do not approach local territories in order to improve them or create businesses and jobs. They come in order to extract profit as fast as possible and as much as possible. Creating jobs makes sense to them only if they can reduce their labour costs. The goal of a typical TNC is to be anywhere in terms of their own benefit and nowhere in terms of 
responsibility (Mander and Goldsmith 1996). Hence, the knot between central corrupted government and financial elites from TNC must be broken and the power of decision making redirected towards local communities by means of building strong local government that would provide for democracy and economic freedom of the community members in the developing and transitional economies. Such a decentralized system of sustainable local communities must be built gradually. Economic localization needs to be preceded by political decentralization and economic democracy built through political democracy that would enable economic governance at the local level. The newly created environment would open space for local ideas, flow on incentives for innovations, knowledge and information and knowledge-based economy can start to be developed by combined top down and bottom up approach.

Economic theory has developed attempts to measure the local development, but no single theory gives a precise definition. Common explanations of some of them can be mathematically expressed as follows:

Local Development $=\mathrm{CxR}$, where $\mathrm{C}$ refers to the capacity of a local territory (economic, social, technological and political) and $\mathrm{R}$ indicates the resources (natural, human resources, locational advantage, capital investments, entrepreneurship culture, transport and communications, technology and industry, market and export potentials). If the value of $\mathrm{C}$ equals 1 , the capacity is neutral, which neither adds up nor takes out value from the resources of the local community. Value higher than 1 indicates strong capacity able to multiply local resources and value lower than 1 refers to low capacity and bad quality of social, organizational and political leadership where corruption, cronyism and interests of a narrow group of people degrade the potential of the local resources and hinder sustainable development. Traditional economic theories focus on the $\mathrm{R}$ part of the equation (resources), neglecting the capacities. Yet, contemporary sustainable development cannot be imagined without a close correlation between the two segments-the more differentiated capacities local community possess, the probability for putting resources in function of sustainability is higher.

In the context of the transitional economies development, both segments need institutional support: 1) improvement of the political, technological, social and overall economic environment for sustainable development and 2) initiating a process of strengthening the resource base, replacing traditional materialistic resources with the creation of knowledge, innovation, connectivity and clustering.

The striking differences between traditional mainstream development and development based on localization (economy of local communities) are presented in Table 2. 
Table 2. Contradicting Characteristics between Mainstream and Local Economics

\begin{tabular}{|l|c|}
\hline Mainstream economy & Economy of local communities \\
\hline Global & Location based \\
\hline Specialized & Diversified \\
\hline Singular & Multifaceted \\
\hline Broad scope & Narrow scope \\
\hline Competitive & Cooperative \\
\hline Centralized & Decentralized \\
\hline Counter cultural & Culture - specific \\
\hline Non local ownership & Local ownership \\
\hline Short term profit & Long term investment \\
\hline Growth oriented & Sustainability oriented \\
\hline Ecologically unsustainable & Ecologically sustainable \\
\hline Amoral & Ethical \\
\hline
\end{tabular}

Source: Gibson-Graham 2006.

\section{Results: In Pursuit of Alternatives}

Transitional and developing economies are in an urgent need of alternative capital sources in order to quit the doomed indebtedness. The corporate state has not seemed to be able to support the creation of sustainable economic entities that would lift the countries from the periphery towards the centre of the global economic map, but rather declared itself as the major capitalist that centralized and sterilized economic vividness, putting the private sector in a position of an instrument of achieving short term political goals of the elites. In support of the thesis, the total external debt stocks of developing countries and economies in transition reached $\$ 6.7$ trillion in 2014, an increase of 5.2 per cent compared with 2013 stocks (World Bank data). Hence, radical moves are necessary for fighting the neo-colonial lock: 1) economic localization (using internal resources and capacities); 2) economic glocalization (establishment of local-global connections); 3) redefinition of the central government function; 4) introduction of sustainable governance principles, Knowledge-Based Economy and change in the general mentality matrix of the citizens. In view of the latter, as per the theory of the Dutch social phycologist, Gerard Hendrik Hofstede ${ }^{2}$, the average mentality in the postcommunist transitional economies is prone to hierarchy, avoidance of risk and entrepreneurship, centralization, politicization, intolerance towards novelties and unconventional ideas, non-participatory decision making and an overall absence of motivation - lacking all that is needed for rising productivity in the era of info and mega - capitalism.

\footnotetext{
${ }^{2}$ Hofstede is a Professor Emeritus of organizational anthropology and international management from the University of Maastricht. He is a former IBM employee, where he has implemented extended researches related to cultural behaviours.
} 
Turning Inwards: Economic Sovereignty of Local Governments a Precondition for Economic Localization

Developing and particularly transitional economies inherited very centralized administrative structures that exercise state intervention into all economic segments. This in combination with the overwhelming global financial capital pressures and converted central state from de jure democratic to de facto corporative provides an unfavourable platform for developing and transitional economies in terms of the ability to improve their geo-strategic position on the global economic map. From a purely economic perspective, the basic platform for exit scenario is maximized employment of domestic economic capacities, available human resource capital, knowledge, skills and information.

Economic localization would be the most logical way out of the negative scenario. This process starts with decentralization of power, transfer of functions and decision making and shifting the focus of economic activities from central to the local level of government. Bottom-up approach is crucial for ensuring economic efficiency and growth via establishing of direct links between local needs and service delivery to citizens and businesses. Decentralization in decision making, as the first step towards economic localization, would open space for effective and efficient use of local resources. Economic activities have to be dismantled at the lowest level of government for giving space to local initiatives, decreasing the distance between supply and demand, the creation of local production systems, trade and participative local government. Local comparative advantages need to be properly advertised and thus create positive competition. The concept of territorial marketing enables these centripetal forces that attract capital at the local level, contrary to the centrifugal forces of the technological development that creates divergences. Economic success is due to an optimal combination of both development forces. Polycentric development policies will further contribute to elimination of disparities, incite internal migration and stimulate growth in less developed regions.

The model of localization implemented in most of the transitional economies is not based on clear economic sovereignty and does not provide for a development platform and benefit for the ultimate beneficiaries, ordinary citizens. De jure, legislation is in place, but de facto, no political will exist for enforcement, all this in combination with the high frequency of corruption practices. Local governments are still very much dependant on the central and the latter does not seem to be interested in giving up power in favour of real growth. Instead, clientele approaches are still maintained for the benefit of the corporate sector. Enabling economic sovereignty at the local level also needs clear fiscal independence, which again is not a case.

\section{Creation of Global-Local Connections}

Contrary to the traditional policies and practices in developing and transitional economies, development is no longer directly connected to the functions of the nation-state in rather developed economies. The ultimate responsibility for 
citizens' welfare is transferred to local level governments in their capacity of important sub-systems of the global politico-economic system. Yet, localization does not mean complete isolation from the global economic scene, to the contrary, it paves the way to glocalization, a sustainability model where local communities, businesses, economic subjects in general, establish direct links with other localities on the global map, thus creating local-global connections. The key element is their complete independence in decision making, a factor crucial for sustainability.

Interactions between economic actors on the global scene vary in the span from cooperation to competition and rivalry. This evident paradoxical behaviour depends on the type of interactions and the final objective of the process. For example, TNC in one industry are fierce rivals, but at the same time cooperate when about to build joint position before the domicile country that would work in favour of both. In the era of info capitalism, capital is super mobile and economic activities are de-territorialized. They can be easily moved from one location to another, yet the inherent connection to the geographical location does not decrease in importance - each economic function is enrooted in a specific location defined by national legal environment, political structure and macroeconomic parameters.

This set-up of global-local production networks dominates the global economic map with clear tendencies towards concentration or dispersion, blurring the traditional national frontiers and integrating national and local economies in ways that exert power over the economic development trends. These processes produce disproportional results in different territories. The contemporary world is different than the one in the $60 \mathrm{~s}$ and $70 \mathrm{~s}$, even though not more inclusive than before, yet more dependant.

\section{Redefining of the Central Government Function}

Developing and transitional economies are faced with radical transformations in view of the socio-economic and political aspects such as decreased power of syndicates and collective bargaining, deficit in democracy, eroded legitimacy of state institutions, diminished power of non-governmental organizations, while neglecting the needs of local businesses and citizens. Economic localization must proceed from radical changes that give a brand new role to central government authorities and would convert them into catalyser and development agent for the local economic subjects. The primary role of the central government needs to be confined to maintaining a stable macroeconomic environment and promoting local economic development policies that would serve as alternative sources for financing debts. This would limit the impact of speculative capital as its import would be reduced.

The new, modern central government and state powers need to work in partnership with the local and create joint policies that ultimately support local community members according to the principle of subsidiarity. The process is multidimensional and certainly two-way. Local community members also need to take direct responsibility and leadership in the local economic development processes (OSCE Mission to Skopje 2013). All these factors lead to improvement 
not only in government models, but also the establishment of new governance practices - participatory, democratic and inclusive.

\section{Implementation of the Democratic Governance Concept via ICT Systems}

ICT development and the overall global economy changes have a major impact on the organization and the implementation of the central and local government functions (Asian Development Bank 2014). The fast info technologies modify the fashion in which governments implement their functions and create instruments for strengthening local democracy by the inclusion of citizens into decision making at the lowest level of government. The transformation of public administration from traditional to contemporary model of governance and the affirmation of the ideas of innovation, effectiveness and efficiency constitute a basic platform for entirely new organizational model of government that is bound to respond to the contemporary needs of citizens. The new model of functional decentralized and socially responsible state directs its policies towards local governments and citizens.

The democratic, good governance concept is as old as the human civilization itself. Landell Mills and Serageldin (Diouf 1991) treat governance aspects such as political responsibility and effective public administration and define governance as "use of political authority and exercising control over for social and economic development", putting the main emphasis on the political and administrative aspects of the governance, but do not explain the complete connection between government and the citizens.

Governance is a system of values, policies and institutions by which government (central and local) influences the economic and the overall human development of the community members and citizens in general. It represents the manner in which government organizes itself for making and implementation of decisions. It includes mechanisms and actions of citizens and communities for identification of their needs and interests, harmonization of their differences and exercising their legal rights and responsibilities. Rules, institutions and practices are those that set boundaries and provide for benefits for individuals, organizations and corporations. Governance, including its social, political and economic dimensions, functions on each and every level, regardless if micro local (household), local (municipality, settlement), regional, national or global. The main driving force, instrument and medium for the functionality of the democratic governance concept are participation, active involvement in its processes with a special accent on the distribution of relevant knowledge and information across the stakeholders' networks. The cooperation is paramount; it is more efficient than competition, a thesis successfully promoted by the Nobel Prize Winner Dr John F. Nash, from Princeton University. The point is as follows: there is a need for maximum cooperation between the government and the service beneficiaries. They are subjects striving towards same goal, they are not competitors. This principle is the main difference between corrupted from one side and transparent and accountable governments on the other (Tremlett 2013). The most convenient level of government that is capable of enforcing an effective governance process in 
line with the community member needs is the local government. This is the starting point in creating contemporary economic development policies. However, practices in developing and transitional economies showcase a high level of political corruption where central government networks by exercising political power force local ones to deviate from fulfilling their basic goal - meeting the different needs of community members. In such a situation, local governments lose their basic function and turn into an extended instrument of the central government in support of the corporative and financial elites' interest.

Contemporary ICT represents a coordination agent among local, regional and central governments, but only if political will exists (Hamnond 2009). Even though in theory the process seems viable, in practice extra efforts are necessary in order to achieve such a synergy, including distinction among different levels of government and combination of the top down and the bottom - up approach. Central governments cannot just transfer resources, functions and power to local ones, without first clearly determining their own new functions and local governments cannot undertake, without policy and legal support from the central governments. Similar to this, e-government cannot isolate itself from the general context of the e-governance. This is a test for the developing and transitional countries of their readiness to position themselves under the supervision of the citizens. Democratic governance needs to be participative, transparent and responsible. Simultaneously, it needs to promote the rule of law in an equitable and effective manner. This ensures that political, social and economic priorities are consensus - based and citizens' orientation principle implemented in the developed and EU countries, fully adopted.

\section{Conclusion}

Central governments need to retain their basic security, defence, macroeconomic and legislative functions for protecting primarily domestic capital and production resources and building basic infrastructure. All direct economic governance processes need to be decentralized to a lower level of government. This repositioning of the central government is a paramount for building protective mechanism against the destructive global economic effects that affect the central government budgets and national policies and are expanding the indebtedness down to the final consumers - the citizens.

The process need not result in isolation of the local communities but to the contrary, need to create a favourable environment for creating new, effective and efficient local-global connections that would benefit the final consumers-citizens, without direct and evident interference of the central government. This process would enable substitution of the formal with informal innovative methods of economic development in line with the authentic needs of the local community members and their local resource potentials. Endogenic local sources are the new driving force and the focus is re-shifted towards sustainability vis-s-vis ever changing global environment. 
The new economic concept of sustainable development is based on the role of informal rather than formal institutions, where nation - states and central governments recognize the economic sovereignty of the local governments. Each contrary policy potentially leads to disintegration proportionally to the degree of exhaustion of the local economies and the transfer of profit to the financial elites via the corporate state mechanisms. Informal institutions are networks, partnerships, clusters that mobilize local sources based on trust and partnership. Informal communication based on trust lead to a decreased transaction costs, sustainability and external influences immunity.

Knowledge, information, innovations and building of innovative systems and networks undertake the primary role in the newly created environment, contrary to the old traditional theories and practices that put the accent on the national economic strategies and budget policies, submitting the local economy to the mercy of the central fiscal transfers. The traditional ineffective and outdated relation: global financial elites - central governments - local governments - citizens is unsustainable and leads to the scenario of "economic secession" of the local territory from the national and represents a bad medium with the global economy.

The sustainable development of developing and transitional economies has to be based on knowledge - based industries that tend to group into Knowledge Based Clusters, local innovation systems organized around universities, research centres and companies that produce innovation. These processes require restored trust among economic stakeholders.

Finally, enhanced social relations among local community members and local public-private partnerships are basic economic development factors of the new technological era, while the local - global networking into industrial, production, trade, service and research and development clusters represent the future of economic sustainability in the changing global environment.

\section{References}

Asian Development Bank (2014) Innovative Asia: advancing the knowledge-based economy: the next policy agenda. Retrieved from: https://www.adb.org/publications/innovative-asia-advancing-knowledge-basedeconomy-next-policy-agenda.

Bartlett W, Uvalic M (2013) The social consequences of the global economic crisis in South East Europe. Research Paper on South Eastern Europe. London: London School of Economics and Political Science.

Bell D (1973) The coming of post-industrial society: a venture in social forecasting. New York: Basic Books.

Ceriani L, Dávalos ME (2014) First insights into promoting shared prosperity in South East Europe. South East Europe Regular Economic Report 5. Europe and Central Asia Region: The World Bank Group.

Dev Singla C (2008) Knowledge-based cluster development in India, opportunities and challenges. Massachusetts: Massachusetts Institute of Technology.

Dicken P (2007) Global shift: mapping the changing contours of the world economy. $5^{\text {th }}$ Edition. London: Sage Publications. 
Diouf J (1991) Comment on "governance and the external factor," by Landell-Mills and Serageldin, and "the cultural dimensions of governance," by Martin. The World Bank Economic Review 5(supplement 1): 321-324.

Down K (2008) Moral hazard and the financial crisis. CRIS Discussion Paper Series VI. Nottingham: Centre for Risk and Insurance Studies, Nottingham University Business School.

Drucker PF (1959) The landmarks of tomorrow. Harper.

Drucker PF (1993) Post capitalist society. Butterwoth-Heinemann.

Gibson-Graham JK (2006) Post-capitalist politics. Minneapolis, MN: Minnesota University Press.

Hahnel R (2012) Of the people, by the people: the case for a participatory economy. AK Press Distribution.

Harari YH (2017) Homo Deus: a brief history of tomorrow. New York, NY: HarperCollins Publishers.

Hilferding R (1981) Finance capital: a study of the latest phase of capitalist development. London: Routledge \& Kegan Paul.

Keynes JM (1932) Economic possibilities for our grandchildren. New York: Harcourt Brace.

Krugman P (2017) Globalization: what did we miss? Retrieved from: https://www.gc.cuny.edu/CUNY_GC/media/LISCenter/pkrugman/PK_globalization. pdf.

List F (1841) The national system of political economy, Retrieved from: https://archi ve.org/details/NationalSystemOfPoliticalEconomyFriedrichList.

Mander J, Goldsmith E (1996) The case against the global economy: and for a turn toward the local. San Francisco: Sierra Club Books.

Mason P (2015) The end of capitalism has begun. The Guardian.

McCraw TK (2007) Prophet of innovation: Joseph Schumpeter and creative destruction. Cambridge, Massachusetts and London, England: The Belknap Press of Harvard University Press.

Mueller P (2016) Adam Smith's criticism of government: knowledge. CATO Institute. Retrieved from: https://www.libertarianism.org/columns/adam-smiths-criticismgovernment-knowledge.

OSCE Mission to Skopje (2013) Implementing citizens participation in decision making at local level. Organization for Security and Co-operation in Europe.

Quigley C (2012) Kondratieff waves and the greater depression of 2013-2020. Financial Sense.

Sen A (1999) Development as freedom. New York: Alfred A. Knopf.

Shachtman M (1962) Introduction to Franz Mehring's Karl Marx. University of Michigan Press, Ann Arbor

Soros G (2011) On globalization. PublicAffairs.

Stiglitz JE (2012) The price of inequality: how today's divided society endangers our future. W. W. Norton \& Company.

Stiglitz J (2015) How I would vote in the Greek referendum. The Guardian.

Tremlett G (2013) Mondragon: Spain's giant co-operative where times are hard but few go bust. The Guardian. Retrieved from: http://1worker1vote.org/mondragon-spainsgiant-co-operative-where-times-are-hard-but-few-go-bust-guardian/.

World Bank Group (2014) Doing business 2015: going beyond efficiency. Retrieved from: https://www.doingbusiness.org/en/reports/global-reports/doing-business-2015.

World Bank Group (2015) FYR Macedonia: public expenditure review fiscal policy for growth. Washington, DC: World Bank. 
Vol. 7, No. $1 \quad$ Jovanova: Sustainable Governance and Knowledge-based Economy...

World Bank Group (2019) Poverty. Retrieved from: https://www.worldbank.org/en/topic/poverty/overview. 